\title{
Fifty-One Years of Naxalite-Maoist Insurgency in India: Examining the Factors that Have Influenced the Longevity of the Conflict
}

\author{
Eric Scanlon
}

\begin{abstract}
The Naxalite-Maoist uprising in India has for fifty-one years continued almost unabated. Today Maoist rebels have a substantial presence in at least ten of India's twenty-nine states and the Indian government has repeatedly stated that it remains the most potent threat to stability that the Indian state faces. This research note examines the existing literature and local primary sources to explore the economic, social, and military factors that have influenced the longevity of this conflict. It details how a fifty-one year conflict has continued almost unmitigated in a country that has the military might that India commands.
\end{abstract}

Keywords India, Naxalites, Maoism, conflict, longevity

\section{Introduction}

May 2018 marked the fifty-first anniversary of the peasant revolt in a little village called Naxalbari, in the Indian state of West Bengal. What seemed like a local uprising soon spread rapidly throughout India and took on a Marxist and Maoist character. As the uprising began in Naxalbari, the insurgents were nicknamed Naxalites, a name which has stuck to this day. The Maoist rebellion has continued almost unabated and today Maoist rebels have a significant presence in ten of India's twenty-nine states (Ministry of Home Affairs 2016). At the height of the Naxalite rebellion in the 2000s it is estimated that they controlled nearly 10 million hectares of mainly forested land. This accounted for about one-seventh of the total forested land in India (Ahuja and Ganguly 2007). Around this same period, it was estimated that the Naxalites had a collection of 15,000 elite men and women under arms (Videl-Hall 2006), a people's militia of 25,000, and 50,000 members in village level units (Navlakha 2006). They have been significantly weakened since then but there is no sign that the conflict will end anytime soon. 
In fact, throughout this conflict's history, every time the Naxalite movement has appeared to be defeated, or in fact physically exterminated, they have recovered and rebuilt themselves stronger, deadlier, and more influential (Roy 2010).

In 2006, Manmohan Singh, then Prime Minister of India, famously stated that the Maoists' pose the "single biggest internal security challenge ever faced by our country" (Ghosh and Das 2010, 2). It was not a ground-breaking acknowledgement because between 2005 and 2009 Naxalites killed more than 900 Indian security personal (Vardley 2009), but it did ensure the federal government focused more on the Naxalite threat and in late 2006 they published their "Status Paper on the Naxal Problem." The paper detailed the government's belief that in order to overcome the Naxalite problem it would have to follow a two-pronged approach by using a combination of military force and economic development measures (IISS 2010). In October 2006, they also created the Left Wing Extremism (LWE) Division in the Ministry of Home Affairs (MHA) to "effectively address the Left Wing Extremist insurgency in a holistic manner" (Ministry of Home Affairs 2017). Yet the war continues to this day and a few months after taking up his post, the current Minister of Home Affairs, Shri Rajnath Singh, said: "LWE still remains the biggest threat to our internal security and nation building process" (Ministry of Home Affairs 2014). This research note will examine the existing literature and local primary sources to explore the economic, social, and military factors that have influenced the longevity of this conflict. It will outline how these three major factors have ensured that the Maoist rebellion has never been entirely crushed and remains such a threat fifty-one years on.

\section{A History of the Naxalite Insurgency}

To understand this war's longevity one must first account for the motives which instigated the uprising, as well as the splits and mergers of different Maoist inspired groups throughout the last fifty years. The 1967 peasant revolt in Naxalbari happened during a period of deep agrarian crisis in West Bengal and other states in India. The crisis was essentially caused by poor weather conditions, but due to the long-term negligence of land reforms by the Indian government, it resulted in widespread deaths by starvation (Banerjee 2009). News of the Naxalbari revolt quickly spread throughout the country by print media and word of mouth, and within two months a revolution influenced by Maoist ideology had officially begun across India (Kujur 2008). Peasant uprisings and struggles were not a new phenomenon in India. For example, between 1783 and 1900 over 100 different cases of violent peasant rebellions are listed as occurring in India's vast rural countryside (Ahuja and Ganguly 2007). However, in 1967 India was no longer a colony and the Maoists were not just fighting for land rights and wage increases that were promised to peasants in post-independent India, they were 
also demanding the complete reshaping of the state. These Maoist revolutionaries were the first movement in independent India to assert "the demands of the poor and landless peasantry in a way that shook the then atrophied Indian political scene" (Banerjee 2002, 2115). However, it must be noted from the outset that this Maoist insurgency was not led by one homogenous group and its character has changed over the decades.

The Maoist insurgency can effectively be placed in three different chronological stages: the first was from 1967 to 1975 , the second from the 1980s to the 1990s, and the third from the 2000s to present. After Naxalbari, and in the first stage, a variety of new Maoist-leftist groups emerged to challenge the state. These included the Communist Party of India Marxist-Leninist (CPI-ML), the Maoist Communist Centre (MCC), as well as the splinter CPI (M-L) Liberation group (Kujur 2008). Although it began as a rural peasant revolt, it was soon greatly influenced by middle-class urbanites that flocked to the countryside to join the insurrection. Consequently, the movement became a "primarily insular, elitecentred endeavour" which lacked "ideological coherence and connection to the poor" (Sen and Teitelbaum 2010, 5). When Indira Gandhi's "emergency" crackdown took hold across India, the Naxalites did not have the mass support they needed and the last embers of the first wave of Naxalite insurgency were brutally but easily smothered (Banerjee 2009). It was not until the lifting of the "emergency" that the movement recovered and began its second phase.

The CPI (M-L) split numerous times throughout the 1970s, particularly after its hugely influential and charismatic General Secretary, Charu Majumdar, died in police custody in 1972. By the end of the decade, CPI (M-L) Liberation became the primary Maoist group and after some of its main leaders were released from jail in the post-emergency period, it began reorganizing and redrawing its ideology. So much so that in the 1980s it began to contest elections and by 1995 it was a recognized political party, but it remains in the political wilderness (Kujur 2008). The move to contest elections was seen as a major revisionist step by committed Maoists, who maintained that the only way to bring about a socialist and communist India was through a protracted people's war. Therefore another splinter group, the CPI (M-L) People's War or simply the People's War Group (PWG), was formed in 1980 by Kondapalli Seetharamaiah in Andhra Pradesh, and it has effectively dominated the political ideology of the contemporary Naxalite movement (Kennedy and Purushotham 2012). As Kujur $(2008,7)$ argues: "If today, Naxalism is considered as the greatest internal security problem and Naxalites claim to be running parallel government in different parts of the country, its credit mostly goes to the PWG."

The PWG did not just concentrate on peasant issues like its predecessors, instead it also focused on workers, tribal communities, women, and other disadvantaged sections of society to form mass organizations and a people's army, instead of a democratic front. This new focus brought the disadvantaged 
directly into the core of the movement and the Indian state could no longer view the Naxalite rebellion as a localized peasant uprising that was easily manageable (Banerjee 2009). However, major fighting within and between Naxalite groups ensured they still did not represent a hugely significant security threat to the central government at this time (Ahuja and Ganguly 2007).

The third wave of the Naxalite struggle has seen the most violent phase of the conflict and the growth of Naxalite activity has been phenomenal. For example, in November 2003 the movement was active in eight states, but by November 2005 it was active in 157 districts across thirteen states (Borooah 2008). One of the primary factors in this increased activity was the merger of the PWG and the MCC into a new CPI (Maoist) party and People's Guerrilla Army (PGA) in 2004. This has increased their support base and escalated their military capacity (IISS 2010). Naxalite membership and the leadership is now drawn from all sectors of the lower classes and castes, and it is a true mass organization, not just a movement directed by middle class urbanites (Videl-Hall 2006). These developments have brought unprecedented success to the Naxalites. In April 2010, Naxalite guerrillas killed seventy-six members of India's Central Reserve Police Force (CRPF), the largest of India's Central Armed Police Forces, in an ambush in the Dantewada district of Chhattisgarh, making it the largest Naxalite attack in history (IISS 2010). The government was shocked into action and had to review how it tackles the Naxalite conflict. While it has historically treated it as a law and order problem, the increased Naxalite activity and support ensured that it now also acknowledges the socio-economic connation of the conflict. The violence weaned in 2015 and 2016 and Naxalites suffered heavy losses in battle, but on April 24, 2017, the Naxalites killed twenty-five CRPF troops in an ambush in the Sukma District of Chattisgarh (Al Jazeera 2017; First Post 2017).

\section{Economic and Land Inequality}

The main instigating factor for the Naxalite insurgency and an incubator of its ideology has been land and economic issues. The Naxalite conflict radically brings to the fore the fact that a large section of the rural poor has been left behind in India's economic leap forward. They do not feature in the "India shining" contemporary model. In fact, the daily life of India's rural peasant has changed little in centuries (Ahuja and Ganguly 2007). In India's vast countryside, land ownership has continued to be immensely skewed in favor of a small landowning upper caste and class elite, to the detriment of the landless majority. Although the problem dates back centuries, it was the zamindari system implemented by the British colonial regime which really laid the foundations of land distribution inequality. The zamindari system institutionalized the role of the zamindaris, or landlords, and endowed them with land titles over tribal land so they could 
extract agricultural surpluses for the East India Company (ibid.). Without the means to acquire land, tribal communities and scheduled castes were unable to better themselves and became dependent on the whims of largely exploitive landlords. In 1953, six years after independence, the Indian government abolished the zamindari system and introduced ceilings on the amount of land an individual could own (Kunnath 2006). However, the landed elite were well placed to lobby the government and both reforms ended up effectively changing little. Landlords ended up being paid richly in "lost revenue" in return for the abolishment of the zamindari system. Additionally, individual landlords just transferred over surplus land to relatives, friends, or factious individuals to escape the ceiling limits (Ahuja and Ganguly 2007). Consequently, since independence, large chunks of India's countryside have been in a state of enduring class and agrarian struggle (Kunnath 2006).

Landlessness ensures that India's downtrodden peasants cannot secure a fixed income, achieve food security, pay for services for their families, and ultimately their survival is primarily in the hands of unscrupulous and oppressive money lenders. Therefore, it is not hard to understand why the Naxalites can wield significant support from India's rural poor when their primary activities are invading and "retaking" land from hated landlords, and taking on societal responsibilities such as providing education, demanding better wages for laborers, irrigation reservoir building, and community kitchens (Ahuja and Ganguly 2010). It is also no surprise that three of the districts where the Maoists have the most support, the Dantewada, Bastar, and Ranjnandagan districts of Chhattisgarh, had 2005 Human Development Index (HDI) scores that matched some of the lowest scores registered in the world, such as Afghanistan and Niger (Ghosh and Das 2010).

Post-independent India has historically tamed violent movements by coaxing the insurgent groups into the country's big-tent political process and personally rewarding leaders with jobs and titles while providing socio-economic guarantees for their people, but this strategy has failed dramatically with the Naxalites (Vardley 2009; Lynch 2016). As Banerjee (2002, 2115) argues: the survival of the Naxalite movement "is due not so much to the prescience of its leaders, as to the Indian state which, with its abysmal failures in socio-economic areas, persists in nourishing the soil for the continuation of the Naxalite movement." It is an argument that was also put forward in a report by a Working Group of the Planning Commission of India in 2001, which maintained that the Indian government's development programs were well designed but their failure lay in the delivery and monitoring of such programs (Ramana 2009). Proof of this can be found in numerous socio-economic development projects. For example, the central government's 1980-81 Integrated Rural Development Programme aimed to enable poor rural families to increase their incomes by providing them with access to credit-based productive assets. Assistance was to be given 
in the form of government subsidies and favorable credit initiatives provided by financial institutions. However, most of the money ended up in the pockets of corrupt local officials, policemen, politicians, traders, and middle men who then supplied these assets to the poor at inflated rates (Ahuja and Ganguly 2007). In more recent times the Right of Children to Free and Compulsory Education Act (2009) and the National Rural Employment Guarantee Act (2005) passed by the central government should have improved the education and income of the poor rural citizens of Maoist affected areas, an extremely important initiative considering that the probability of a district being Naxalite affected rose with an increase in its poverty rate and fell with a rise in its literacy rate (Borooah 2008). Yet the implementation of these programs has been massively hindered by the corruption of local officials and politicians (Ghosh and Das 2010). Incompetent institutions headed by inept and corrupt officials have only deepened the mistrust peasants have for the central and state governments, and increased the support for the Naxalites (ibid.).

When real tangible land reforms and socio-economic programs are implemented, the Naxalites have lost their support base. Nowhere has this been more prevalent than in Naxalbari village, where the short-term benefits of small plots of cultivable land, higher wages for labor, and a partial voice in local government institutions implemented by the Left Front government ensured that Naxalbari peasants shunned the Maoists (Banerjee 2009). However, one must remember that this was before the Naxalites grew their support base and became a mass movement in the second and third waves of the struggle. Nevertheless, one of the primary factors in the Naxalite's longevity is that there is little effort by the central and state political leadership to reassure poor rural citizens that a democratic polity will listen to their demands and provide effective solutions to their problems. As the Andhra Pradesh based journalist K. Srinivas Reddy maintains: "Even if a minuscule section of society finds relevance in revolutionary politics, the blame squarely lies with the politician and administrator" (Ramana 2009, 754).

Furthermore, in recent times India has also embraced a rigid neo-liberal economic model which has created rapid economic growth and made it an emerging global power, but it has also deepened inequalities, particularly in its rural areas (Vardley 2009). Not only has the Indian government not distributed the benefits of its newfound economic growth evenly, but it is increasingly forcing rural peasants off their land so that it can tap into the lucrative resources and minerals underneath fertile agricultural land, particularly in its forests. Although India's peasants have tilled some of this land for centuries, the vast majority don't legally own any of it and hungry industrialists are attempting to swallow it rapidly (Videl-Hall 2006). This has occurred because successive Indian governments have failed to implement the fifth and ninth schedules of the Indian Constitution which deal with forest reserves and land legislation (Prasanna 2016). Companies 
and non-indigenous individuals are prohibited from directly buying land owned by tribal members in regions with dense tribal populations. However, the law allows the government to acquire the land and then sell it to third parties, and this is what is occurring, much to the fury of the indigenous locals (Bahree 2010). Therefore, resistance against land grabs in Chhattisgarh, Jharkhand, and Orissa are now a bigger political platform for the Naxalites than the traditional movement for land redistribution (Basu and Das 2013).

When corporate officials and government politicians state that the Maoists are obstructing the development of rural areas, in reality they mean that they are obstructing the corporate exploitation of the minerals, forests, water, and land resources of peasants. The payoff for local communities in this scenario is capital-intensive, low-job-creating investments which necessitate an importation of skilled labor, and token employment for a small number of unskilled low wage laborers (Navlakha 2006). It is not surprising that peasants distrust the government's motives and do not believe their promises of wealth distribution from the lucrative mining trade. According to B. Mungekar, a member of India's Planning Commission, between 1951 and 1990, 40 million people were moved off their land or displaced in rural and urban India. Forty-five percent of the people displaced were poor members of tribal communities and only 25 percent of the displaced have been reimbursed (ibid.). Additionally, practically all of India's proven coal reserves are in eight states (Ministry of Coal 2014), making it unsurprising that all of them also have a significant Naxalite presence. While mining activities are limited in their geographical range and cannot account for the widespread nature of the conflict and the Naxalites' geographical reach (Sen and Teitelbaum 2010), the role of the Naxalites as the perceived defenders of peasant interests against exploitive corporations and corrupt governments has gained them large support among furious and fearful peasant communities.

\section{Caste and Social Division}

When we speak of peasant support for the Naxalites, we must not be content with describing them as a homogenous economic group. In fact, not only is Naxalite support drawn from poor peasants, but the vast majority are dalits (Scheduled Castes) or adivasis (Scheduled Tribes), as well as other so-called "backward classes" (Borooah 2008). Although some of the group's leaders are educated middle class urbanites, the vast majority of the guerrillas are now from marginalized rural dalit and adivasi communities (IISS 2010). This is very important for understanding why the Naxalites have had support throughout India's countryside for five decades. Besides the chronic poverty, starvation, and economic exploitation that is the main stay of peasant life in India, if you are a dalit or adivasi you face humiliating discrimination and ostracization at the 
bottom rung of the social hierarchy (Ahuja and Ganguly 2007). This demeaning and inhumane treatment of dalits and adivasis, and the ability of the Naxalites to mobilize these communities around common economic and social grievances, ensures the movement maintains a rural support base (Sen and Teitelbaum 2010).

Even though untouchability and caste discrimination were abolished under India's Constitution in 1950, caste bias remains deeply engraved in the public psyche, especially in rural areas (Ahuja and Ganguly 2007). In fact, the plight of the scheduled castes and scheduled tribes is described by the academic Ashutosh Varshney as one of the unfinished quests of Indian democracy (quoted in Vardley (2009)). Therefore, to some, the Naxalites represent the only beacon of hope for an oppressed people that have been repeatedly ignored and exploited by their own government and local officials. Banerjee $(2009,259)$ details a meeting with an old peasant of a scheduled caste in West Bengal in 1969. When Banerjee asked the old man whether he felt any difference since the Naxalite uprising, the man replied: "Yes! I can now walk with my head straight up, and do not have to make way, even when I cross the path of my landlord." The practice of lower castes and tribal community members in rural areas bowing their heads whenever they came across their upper castes neighbors, as a sign of subservience, is a demoralizing and humiliating act. By stamping out such callous practices the Naxalites have helped bring pride and respect among dalits and adivasis, and thus support among sections of these groups should not come as a shock.

However, although the issue of class and caste command a lot of the Naxalite's revolutionary writing and teaching, the interlinked issue of patriarchy has not historically featured as much. A large number of tribal, peasant, and urban middle class women participated in the first stage of the Naxalite rebellion, but they have largely been written out of the historiography of this period, and the Naxalite movement was accused of being gender blind at the time (Kamra 2013). Furthermore, Sinha Roy (2006) has pointed out that while Charu Majumdar wrote a number of essays addressing different sections and classes of society, which became massively influential literature to the Naxalite movement in the first stage of the rebellion, not one of these essays was focused on women. However, it is important to note that the Naxalite movement created a space where, for the first time, young, married and unmarried Indian women could challenge the regulatory control of their families and society in both urban and rural settings (Roy 2007).

The contemporary Maoist movement has engaged much more with women's issues and feminist ideology, and the number of women joining the modern Naxalite campaign is higher than the number of men. Considering the repressive societal pressures and violence that Indian women face, particularly in rural areas, this is not a surprise. PWG was the first Naxalite group to really engage when it produced its document "Our Approach to the Women's Question" (Kamra 2013). Since then, Naxalite leaders have opened up debate among supporters as 
to how to better weave feminism into the movement. Furthermore, when the CPI (Maoist) was established it produced a little red book on women's issues. The diversity and prioritization of the issues that it grapples with speaks volumes about the influence that feminist discourse has had on the contemporary Naxalite movement (Kannabiran, Volga, and Kannabiran 2004). An econometric data analysis undertook by Borooah (2008) also shows that, after controlling for a variety of variables, Naxalite activity in a district has a dampening effect on violent crimes committed against women, a major problem in India's rural districts. In comparison, the state's violent counterinsurgency operations have specifically targeted women, whether they are Naxalites or not, and rape and sexual violence have become core instruments of its counterinsurgency programs (Shankar 2016). Any woman who does not adhere to patriarchal norms in Naxalite affected areas can be automatically deemed a Naxalite and as a consequence suffer horrific violence and sexual abuse (ibid.). This too has played its part in recruiting women to either join or support the Naxalite movement.

It must also be noted that violent uprisings by lower caste and tribal peasants in India have not been isolated to the fifty-one years of the Naxalite rebellion. Historical records show that oppressed dalits and adivasis have rebelled against their oppressors' numerous times over the previous centuries (Banerjee 2009). This is particularly true of the tribal communities of central India who have a history of rebellion which outdates Maoism by hundreds of years. As Roy (2010) points out, this is a truism, because if they did not violently rebel during these times they would not in fact exist today. However, we must not generalize India's rural dalits and adivasis as inherently violent and ready to join a revolution at any time, as this obviously is not the case. Furthermore, the class consciousness and political awakening of the scheduled castes and scheduled tribes by Maoist ideology must also not be taken for granted. The Naxalites have been particularly successful in spreading their brand of Marxism in rural and isolated areas, while also using the rich rebellious history of India's dalits and adivasis to rationalize and institutionalize their violent insurgency among the peasant communities (Banerjee 2009).

The Naxalites popularity among the marginalized lower castes and tribal communities' stems from their ability to directly and forcefully challenge the Indian state over its failed promises to these groups since independence (Ahuja and Ganguly 2007). Welfare projects, housing programs, and loan schemes were offered to these communities as a way of obtaining their active consent to the existing socio-economic structure, but they were never delivered by the government. As Roy (2010) points out: "In exchange for the right to vote, it snatched away their livelihood and dignity." The failure to provide meaningful socio-economic reforms has ensured that some of these communities have instead decided to support the revolutionary Maoist model. In spite of this threat, the Indian polity continues to be characterized by broken promises, corruption, 
and remains unsympathetic to the socio-economic demands of dalit and adivasi peasants. So even though the Naxalites have been unable to completely end the repression by at least challenging it and offering a beacon of hope, they have been able to imbed themselves in certain dalit and adivasi communities, and particularly with women (Kunnath 2006).

\section{The Military Response}

The final major factor in the longevity of the Naxalite movement has been the poor and often disastrous response of both central and state governments. The Indian state has primarily acted in a militaristic manor to crush the Naxalites in their strongholds (Banerjee 2009). This has had a disastrous effect on India's rural hinterland, particularly during the current phase of the Naxalite conflict. While the Naxalites have historically never really been known for their military prowess, since the creation of the CPI (Maoist) they have successfully executed daring raids that have jolted policymakers in Delhi (Sen and Teitelbaum 2010). Although this strength is due in part to their new-found unity, in recent years the Naxalites have also created growing alliances with international guerrilla armies. This has vastly improved their firepower and bomb making techniques (Ahuja and Ganguly 2010). They are believed to have had sustained contact with the Liberation Tigers of Tamil Eelam (LTTE) for weapons and land mine training, and the CPI (Maoist) is a member of the Coordination Committee of Maoist Parties and Organisations (CCOMPOSA), which aims to coordinate and unify Maoist groups in South Asia (ibid.). Their deadly new capabilities can be seen in recent casualty figures-an estimated 1,852 security force personal were killed by Naxalites between 2005 and 2016 (SATP 2017).

One of the key failings of the Indian authorities' military response is the lack of coordination between state governments. While Naxalite affected states have been generally supportive of central government decisions, there has been little inter-state cooperation. The Naxalites obviously do not pay much attention to state boundaries or administrative units, and the response of state authorities to act independently of each other plays into the hands of the Naxalites. Therefore, state borders are sensitive to attacks as the Maoists can strike in one state and flee over the border knowing the authorities cannot follow them (IISS 2010). While Delhi could become directly involved in the conflict by using the army and air force against the Naxalites, the use of the regular armed forces against a domestic threat is unpopular in military circles and among the wider Indian public. This was acknowledged by the Cabinet Committee on Security and, in June 2010, they decided that the regular armed forces would retain an advisory/ training and evacuation/transport role in the conflict, as opposed to being on the frontline (ibid.). The resistance to using the regular armed forces is also 
because the Naxalites do not threaten India's external borders and sovereignty, unlike the insurgency in Kashmir and in the Northeast. While the Naxalite insurgency is widespread, it is now largely contained in central and remote parts of India. Furthermore, although China initially showed interest and enthusiasm towards the Naxalites in the first phase of the movement, this has tapered off, and therefore none of India's neighbors are supporting the Maoist rebellion (Ramana 2011). Hence, India continues to adopt a counterinsurgency strategy which focuses on kinetic military operations involving state paramilitary forces (Lynch 2016).

The government launched a massive counterinsurgency program on November 17, 2009 called Operation Green Hunt (Ghosh and Das 2010). The campaign involved training police units and sending up to 200,000 paramilitary troops deep into jungle and forest communities to confront the Maoists and drive them out of their strongholds (Vardley 2009; Lynch 2016). The most contentious and counterproductive military move in this period was the sponsoring of vigilante groups, such as the now infamous Salwa Judum "counterinsurgency" militia. Salwa Judum, which literally means "Purification Hunt," was created in 2005 and operated in Chhattisgarh. It was an informal organization comprised of both local villagers and out-of-state opportunists that numbered between five and ten thousand. Its aim was to violently and brutally crush the Naxalite movement by any means necessary (Miklian 2009). The government maintained that Salwa Judum was a local spontaneous eruption of the people against the heavy-handed methods of the Naxalites. However, Chhattisgarh state authorities backed and supported Salwa Judum activists and even appointed some of them as Special Police Officers (SPOs), providing them with a monthly stipend (Ramana 2009). Mining companies and officials also paid the Salwa Judum to protect their employees and to forcibly expropriate mineral-rich land from dalit and adivasi villagers. Their land grabs allowed the mining corporations to operate without the extensive delays and profit-sharing programs that acquiring tribal land entails when done through legal channels. It was essentially a land grab masquerading as a local uprising (Miklian 2009).

The National Human Rights Commission quickly accused the group of grave human rights abuses (Borooah 2008). However, impunity remained the order of the day and Salwa Judum brazenly attacked and burned down any villages they unilaterally suspected of being pro-Naxalite (Miklian 2009). While Salwa Judum actively recruited desperate and downtrodden residents with the prospects of earning a good income, the fear of being resettled in the notorious Internally Displaced Peoples (IDP) camps and the crimes of the Salwa Judum also acted as a recruiting tool for the Naxalites (Chakravarti 2008). Ultimately, they further militarized rural societies, entrenched the Naxalite conflict, acted as a recruitment tool for the Naxalites, and cleansed mineral rich areas of their indigenous populations, all in the name of bringing peace. Therefore, instead of 
quelling the Naxalite uprising in Chhattisgarh, the conflict became exponentially deadlier after Salwa Judum's formation. In July 2011, the Indian Supreme Court declared the arming of Salwa Judum by Chhattisgarh state authorities and their appointment as SPOs unconstitutional (Khosla 2011). In May 2013, Mahendra Karma, who played a significant role in the foundation of Salwa Judum, was killed in Bastar district in Chhattisgarh by the Maoists after they ambushed the convey in which he was travelling. After the attack, the Maoists released a statement claiming the ambush was set to specifically target Karma and punish him for his role in creating Salwa Judum. Eye witnesses reported that he was repeatedly stabbed by female Naxalite combatants and his post mortem revealed he was stabbed 78 times (Naveen 2013).

While in opposition and in government, Indian Prime Minister Narendra Modi has maintained a deeply masculine public discourse that expresses distain for those that get in the way of his Hindutva and neo-liberal policies (Kothari 2014; Varma 2017). It is therefore no surprise that he has advocated a zerotolerance approach to the Naxalites (Kumar 2015). When the Modi government first came to power, much was made of how it would deal with the Naxalites and many thought it would support Salwa Judum like outfits. It soon produced a new twenty-nine point "National Policy and Action Plan to Address Left Wing Extremism" (Singh 2015) and the MHA estimated that 2015 saw the lowest violence in the war in six years (Times of India 2016). However, if you look deeper, Naxalite violence had been falling since 2010, four years before Modi became Prime Minister, and the plan was basically a continuation of the policies followed by the previous government; there were no radical new approaches (Routray 2015). Indeed, the only new proposal seemed to be a declaration by the MHA that plans to tackle support for the Naxalites by giving adivasis more recognition through official support for the celebration of their festivals and by naming roads and airports after their icons (Tripathi 2014). This seems more of a sop to the BJP's Hindutva base rather than a thought-out policy of significance.

In Chhattisgarh, the ruling BJP state level government recently launched "Mission 2016" which follows the old model of supporting armed militias groups, some of which are led by former Salwa Judum commanders. It is a program that uses state violence to suppress all voices of dissent against neo-liberal Hindutva policies (Trivedi and Ramakrishnan 2016). This is particularly acute in the Bastar district of Chhattisgarh where community leaders have been arrested on trumped up charges and abused in detention. Journalists and lawyers who have revealed police abuses in Bastar and worked on legal cases to free community activists have also been targeted by the police and state forces, and accused of being Maoist sympathisers (Patel 2016). Most Naxalites and suspected Naxalites continue to be killed in "encounters," which are usually faked by the police to cover up police torture and extrajudicial killings (Das 2016). The Indian state is therefore paradoxically trying to undermine support for the Naxalites among 
adivasis and dalits by forcing on them an economic, bureaucratic, and legal process that has fuelled their grievances for decades. Anyone who speaks out then faces violent state repression, which was also an original root cause of the conflict (Kennedy and Purushotham 2012). Although Naxalite violence was decreasing, it spectacularly jumped back into the national and international news after a Maoist ambush of the CRPF in Chhattisgarh in April 2017 claimed the lives of twentyfive soldiers, the highest state losses in a single attack since 2010 (Al Jazeera 2017). This made everyone once again aware that this fifty-one year old conflict is far from finished.

\section{Conclusion}

There are three distinct factors which have ensured that the Naxalite insurgency has lasted for fifty-one years and will likely continue into the near future. The first is that the Indian state has failed to implement meaningful land reforms since independence and promises in this regard have been repeatedly broken, leaving rural peasants in a state of impoverishment that has changed little in centuries. It has also neglected to tackle the deep-rooted economic inequalities that particularly effect its rural citizens. Furthermore, it is now displacing and further impoverishing millions of them in its lust for minerals and natural resources. These factors ensure that the Naxalites can continue to retain support in their rebellion against a state indifferent to the economic woes of daily peasant life.

The second factor is the continued caste and social divisions that remain intact in India. Caste and tribal based discrimination was outlawed in India's Constitution but it is still imprinted in the social psyche, especially in the rural areas where the Naxalites have significant support. Moreover, the plight of women in repressive patriarchal rural communities and the violence they face has ensured that more women than men are now joining the Maoist insurgency. This has also seen the Naxalites become more influenced by feminist discourse. As long as the Naxalites attack these inhumane social structures they give hope and empower women, dalits, and adivasis to continue the rebellion. Additionally, the history of lower castes and tribal communities violently rebelling against the authorities is a long one, and this allows the Naxalites to continue to justify and legitimize their fifty-one year old struggle in their heartlands.

The third factor that has influenced the longevity of the conflict is the poor and inflammatory responses of the Indian government. By maintaining weak cooperation between state governments in their military responses to the conflict the central government has allowed Naxalites to thrive in border areas. The worst policy of the government, however, was the covert sponsoring of Salwa Judum and other militias. Their human rights abuses and brutal tactics have only inflamed the conflict and driven a portion of the peasant youth towards 
the Naxalites. This counterproductive state repression does not look like it will end anytime soon and the counterinsurgency is increasingly being used to crack down on all civil society activists who protest state violence and corruption.

Ultimately, the longevity of the conflict and the continued support for the Naxalites among a significant section of India's rural peasants is due to the failure of the Indian state to bring tangible economic development and social change to these rural communities. When violent conflict developed the government's military response only added fuel to the fires of rebellion. The responsibility for the failings of the government does not lie with a few individuals but instead in a political culture which accepts corruption, ineptitude, and greed, as well as a government which lacks oversight. It is too early to judge the effect that Modi's government will have on the longevity of the conflict and if it can end it, but it clearly seems to be following the same failed policies of successive Indian governments. Attempts at peace talks continue to flounder due to the preconditions each side demands and there is currently a dire lack of appetite for such a peace process on both sides. While the Maoists are currently on the backfoot they are far from beaten, as the April 2017 attack in Chhattisgarh showed. Therefore, as long as the state's authorities respond in their usual corrupt and impassive fashion the Naxalite rebellion will continue to be supported by a section of India's downtrodden. Ultimately, although the CPI (Maoist) flag will not fly over Delhi's Lal Qila anytime soon, the conflict's resolution also does not seem imminent.

\section{References}

Ahuja, Pratul, and Rajat Ganguly. 2007. “The Fire Within: Naxalite Insurgency Violence in India." Small Wars \& Insurgencies 18 (2): 249-274.

Al Jazeera. 2017. "Maoists' Kill 25 Troops in Worst Attack in Seven Years." April 25. http:// www.aljazeera.com/news/2017/04/chhattisgarh-suspected-maoist-rebels-kill-12soldiers-170424124924656.html (accessed August 31, 2018).

Bahree, Megha. 2010. “The Forever War: Inside India's Maoist Conflict.” World Policy Institute 27 (2): 83-89.

Banerjee, Sumantra. 2002. "Naxalbari: Between Past and Future." Economic and Political Weekly 37 (22): 2115-2116.

Banerjee, Sumantra. 2009. "Reflections of a One-Time Maoist Activist." Dialect Antropal 33 (3-4): 253-269.

Basu, Deepankar, and Debarshi Das. 2013. “The Maoist Movement in India: Some Political Economy Considerations.” The Journal of Agrarian Change 13 (3): 365-381.

Borooah, Vani K. 2008. "Deprivation, Violence, and Conflict: An Analysis of Naxalite Activity on the Districts of India." International Journal of Conflict and Violence 2 (2): 317-333.

Chakravarti, Sudeep. 2008. Red Sun: Travels in Naxalite Country. New Delhi: Penguin 
Books.

Das, Raju J. 2016. "Social Movements and State Repression in India." Journal of Asian and African Studies 52 (8): 1080-1102.

First Post. 2017. "Naxal Attack in Chhattisgarh's Sukma: How 300 Maoists Attacked 99-Member CRPF Troop." April 25. http://www.firstpost.com/india/all-you-need-toknow-about-naxal-attack-in-sukmas-chhattisgarh-300-maoist-guerillas-attacked-99member-crpf-troop-3402786.html (accessed August 31, 2018).

Ghosh, Souparno, and Sourish Das. 2010. "Spatial Point Process Analysis of Maoist Insurgency in India." Technical Report \#2010-3, Statistical and Applied Mathematical Sciences Institute, June 19. http://www.samsi.info/sites/default/files/tr2010-03.pdf (accessed August 31, 2018).

IISS (International Institute for Strategic Studies). 2010. “India’s Maoist Challenge.” IISS Strategic Comments 16 (24). https://www.tandfonline.com/doi/abs/10.1080/1356788 8.2010.523184? journalCode=tstc20 (accessed October 26, 2018).

Kamra, Lipika. 2013. "Self-Making Through Self-Writing: Non-Sovereign Agency in Women's Memoirs from the Naxalite Movement." South Asia Multidisciplinary Academic Journal 7.

Kannabiran, Vasanath, Volga, and Kalpana Kannabiran. 2004. "Women's Rights and Naxalite Groups." Economic and Political Weekly 39 (45): 4874-4877.

Kennedy, Jonathan, and Sunil Purushotham. 2012. "Beyond Naxalbari: A Comparative Analysis of Maoist Insurgency and Counterinsurgency in Independent India." Comparative Studies in Society and History 54 (4): 832-862.

Khosla, Madhav. 2011. "Salwa Judum and the Supreme Court." The Hindu, July 13 (Updated August 16, 2016). https://www.thehindu.com/opinion/lead/salwa-judum-and-thesupreme-court/article2221935.ece (accessed August 31, 2018).

Kothari, Ashish. 2014. "A Hundred Days Closer to Ecological and Social Suicide." Economic and Political Weekly 49 (39): 10-13.

Kujur, Rajat. 2008. "Naxal Movement in India: A Profile." IPCS Research Paper, Institute of Peace and Conflict Studies, September. http://www.ipcs.org/issue_briefs/issue_brief_ pdf/848082154RP15-Kujur-Naxal.pdf (accessed August 31, 2018).

Kumar, S. Y. Surendra. 2015. "Nonviolent Measures to Deal with Naxalism in India: An Assessement of Government's Response." Thammasat Review 18 (1): 84-101.

Kunnath, George J. 2006. "Becoming a Naxalite in Rural Bihar: Class Struggle and its Contradictions." The Journal of Peasant Studies 33 (1): 89-123.

Lynch, Tomas F. 2016. "India's Naxalite Insurgency: History, Trajectory, and Implications for US-India Security Cooperation on Domestic Counterinsurgency." Strategic Perspectives 22 (October): 1-41.

Miklian, Jason. 2009. "The Purification Hunt: the Salwa Judum Counterinsurgency in Chhattisgarh, India." Dialect Antropal 33 (3-4): 441-459.

Ministry of Coal. 2014. "Coal Reserves.” Accessed August 31, 2018. https://coal.nic.in/ content/coal-reserves.

Ministry of Home Affairs. 2014. "Left Wing Extremism Discussed in the Consultative Committee Meeting." November 12. http://pib.nic.in/newsite/PrintRelease. aspx?relid=111325 (accessed August 31, 2018).

Ministry of Home Affairs. 2016. "LWE affected districts.” February 24. http://pib.nic.in/ newsite/PrintRelease.aspx?relid=136706 (accessed August 31, 2018). 
Ministry of Home Affairs. 2017. "Information on LWE Division.” https://mha.gov.in/ division_of_mha/left-wing-extremism-division (accessed October 26, 2018).

Naveen, P. 2013. "Women Maoists Stabbed Congress Leader Mahendra Karma 78 Times". Times of India. May 29. https://timesofindia.indiatimes.com/india/Women-Maoistsstabbed-Congress-leader-Mahendra-Karma-78-times/articleshow/20319599.cms (accessed August 31, 2018).

Navlakha, Gautam. 2006. "Maoists in India." Economic and Political Weekly 41 (22): 21862189.

Patel, Aakar. 2016. "Bastar, A Taste of Things to Come." Outlook India. February 28. https:// www.outlookindia.com/website/story/bastar-a-taste-of-things-to-come/296691 (accessed August 31, 2018).

Prasanna, Sandeep Avinash. 2016. "Red Belt, Green Hunt, Grey Law: India’s NaxaliteMaoist Insurgency and the Law of Non-International Armed Conflict." UCLA Law Review 63 (2): 488-527.

Ramana, P. V. 2009. “A Critical Evaluation of the Union Government's Response to the Maoists Challenge." Strategic Analysis 33 (5): 745-759.

Ramana, P.V. 2011. "India's Maoist Insurgency: Evolution, Current Trends, and Responses." In India's Contemporary Security Challenges, ed. Michael Kugelman, 29-46. Washington D.C.: Wilson International Centre for Scholars.

Routray, Bibhu Prasad. 2015. "Naxal Violence in 2015.” Institute of Peace and Conflict Studies (IPCS) Forecasts, Special Report No. 173 (January): 1-22.

Roy, Arundhati. 2010. "Walking with the Comrades." Outlook India, March 29. https:// www.outlookindia.com/magazine/story/walking-with-the-comrades/264738 (accessed August 31, 2018).

Roy, Srila. 2007. “The Everyday Life of a Revolution: Gender, Violence and Memory." South Asia Research 27 (2): 187-204.

Sen, Rumela, and Emmanuel Teitelbaum. 2010. "Mass Mobilization and the Success of India's Maoists." Paper Presented at the Ralphe Bunche Forum, Ralphe Bunche Institute for International Studies, City University of New York, September 30. http:// www.academia.edu/352458/Mass_Mobilization_and_the_Success_of_Indias_Maoists (accessed August 31, 2018).

Shankar, C. S. R. 2016. "In a Corner of Bastar, Sexual Assault by the Police Has Not Destroyed the Hope for Justice." The Wire, October 4. https://thewire.in/rights/lawand-life-in-bijapur-a-story-of-everyday-violence-on-women-police-brutality-andimpunity (accessed August 31, 2018).

Singh, Rakesh K. 2015. "Modi Govt Firms Up Anti-Naxal Strategy." The Pioneer, May 31 2015. https://www.dailypioneer.com/todays-newspaper/modi-govt-firms-up--antinaxal-strategy.html (accessed August 31, 2018).

Sinha Roy, Mallarika. 2006. "Speaking Silence: Narrative of Gender in the Historiography of the Naxalbari Movement in West Bengal (1967-75)." Journal of South Asian Development 1 (2): 208-230.

SATP (The South Asian Terrorism Portal). 2017. "Fatalities in Left-wing Extremism: 1999-2016." http://www.satp.org/satporgtp/countries/india/maoist/data_sheets/ fatalitiesnaxal05-11.htm (accessed August 31, 2018).

Times of India. 2016. “2015 Saw Lowest Naxal Violence in 6 Years.” January 31. https:// timesofindia.indiatimes.com/india/2015-saw-lowest-Naxal-violence-in-6-years/ 
articleshow/50791568.cms (accessed August 31, 2018).

Tripathi, Rahul. 2014. "NDA's New Anti-Naxal Doctrine Promises to Deal with Violence More Effectively." India Today, October 16. https://www.indiatoday.in/magazine/ nation/story/20141027-nda-government-naxal-modi-policy-terror-upa-adivasis805544-2014-10-16 (accessed August 31, 2018).

Trivedi, Divya, and Venkitesh Ramakrishnan. 2016. "War on Bastar." Frontline, April 13. https://www.frontline.in/cover-story/war-on-bastar/article8465544.ece (accessed August 31, 2018).

Vardley, Jim. 2009. "Maoist Rebels Widen Deadly Reach Across India." New York Times, October 31. http://www.nytimes.com/2009/11/01/world/asia/01maoist.html (accessed August 31, 2018).

Varma, Rashmi. 2017. “(Un) Modifying India: Nationalism, Sexual Violence, and the Politics of Hindutva." Feminist Dissent 2: 57-83.

Videl-Hall, Judith. 2006. “Long Walk in a Deep Forest." Index on Censorship 35 (4): 73-75.

Eric Scanlon is a political advisor on Foreign Affairs for the Irish political party, Sinn Féin, working in the Irish Parliament, Dáil Éireann. He has BA in International Relations and an MA in Development Studies from Dublin City University. He is a first year PhD student in the Irish School of Ecumenics in Trinity College Dublin. His research is examining the role of foreign political parties in peace processes since the end of the Cold War. Email: scanloer@tcd.ie 
